\title{
ANALISIS FAKTOR-FAKTOR YANG MEMPENGARUHI KEPUTUSAN PENETAPAN UMK DI WILAYAH BARLINGMASCAKEB
}

\author{
Ghonimah Zumroatun Ainiyah ${ }^{1}$, Dwi Adiyasha ${ }^{2}$ \\ STIE TamansiswaBanjarnegara Jl. Mayjend Panjaitan No. 29 Banjarnegara \\ Email : eny.wsb@gmail.com ${ }^{1}$, dwiady26@gmail.com²
}

\begin{abstract}
The objective of this research was to find out the effect of Adequate Standard of Living (KHL), Consumer Price Index (IHK), and Gross Regional Domestic Product on the decision to determine regencies minimum wage $(U M K)$ in Banjarnegara, Purbalingga, Banyumas, Cilacap, and Kebumen (Barlingmascakeb). The data were taken from the Indonesian Center for Statistics (BPS).

This study used quantitative research. The data used in this research was secondary data. The population in this study was people from the Barlingmascakeb area with observational methods from 2010-2016. Saturated samples technique used in this research. Data analysis in this study used panel data regression analysis with SPSS 24 software.

The result showed that based on regional panels, KHL partially has a positive and significant effect on the decision to determine regencies minimum wage in the Barlingmascakeb area. Whereas the IHK and PDRB have a negative and not significant effect on the decision to determine regencies minimum wage in the Barlingmascakeb area. Based on the time area, partially the KHL and PDRB have a positive and significant effect on the decision the determine regencies minimum wage in the Barlingmascakeb area. While IHK has a negative and not significant effect on the decision to determine regencies minimum wage in the Barlingmascakeb area.
\end{abstract}

Keywords: Adequate Standard of Living (KHL), Consumer Price Index (IHK), and Gross Regional Domestic Product, Regencies Minimum Wage (UMK)

\section{PENDAHULUAN}

\section{Latar Belakang}

Ketenagakerjaan menjadi salah satu permasalahan penting yang perlu diperhatikan di setiap negara, khususnya di Indonesia. Selama ini pemerintah memandang masalah ketenagakerjaan hanya pada bagaimana menangani masalah angkatan kerja yang semakin meningkat namun kesempatan kerja yang

Vol. 11, No. 1, Juli 2020, Halaman 45-58 tersedia sangatlah terbatas. Akan tetapi masih banyak lagi permasalahanpermasalahan tentang ketenagakerjaan lainnya. Salah satunya adalah masalah upah yang diberikan kepada tenaga kerja. Panorama dan Lemiyana (2014) mendefinisikan upah sebagai imbalan yang diterima selama sebulan oleh buruh/karyawan baik berupa uang atau barang yang dibayarkan 
perusahaan/kantor/majikan. Upah minimum adalah upah bulanan terendah yang terdiri atas upah pokok termasuk tunjangan tetap yang ditetapkan oleh gubernur sebagai jaring pengaman.

Di Indonesia, masing-masing daerah menetapkan upah minimum yang berbeda-beda. Hal tersebut tergantung pada karakteristik dari masing-masing daerah yang berbeda-beda. Beberapa daerah yangproduktif dalam sektor industri akan menetapkan upah minimum yang tinggi, karena disesuaikan dengan karakteristik dan pertumbuhan ekonomi dari daerah tersebut dan juga faktor lainnya.

Dalam penetapan upah minimum, pemerintah menggunakan beberapa indikator sebagai dasar pertimbangan. Salah satu indikator penetapan Upah Minimum adalah Kebutuhan Hidup Layak (KHL). Menurut Keputusan Menteri Tenaga Kerja No. 13 tahun 2012, standar KHL yang digunakan untuk penetapan upah minimum terdiri dari beberapa komponen yaitu makanan dan minuman (11 unit), sandang (13 unit), perumahan (26 unit), pendidikan (2 unit), kesehatan (5 unit), transportasi (1 unit), dan rekreasi dan tabungan (2 unit). Indikator lain dalam penetapan upah minimum adalah Indeks Harga Konsumen (IHK). Menurut
Macroeconomic (2017), Indeks Harga Konsumen adalah indeks perubahan biaya hidup. Kenaikan harga-harga yang berlaku dari suatu waktu tertentu ke waktu yang lainnya tidak berlaku secara seragam Sulistiyo dan Insukindro (2009) mendefinisikan PDRB sebagai nilai bersih barang dan jasa-jasa akhir yang dihasilkan oleh berbagai kegiatan ekonomi di suatu daerah dalam suatu periode tertentu. Produk domestik suatu wilayah merupakan nilai seluruh produk dan jasa yang di produksi di wilayah tersebut. Kenaikan PDRB akan menyebabkan pendapatan dari sektor pajak dan retribusi meningkat. Hal tersebut akan berdampak pada peningkatan Pendapatan Asli Daerah (PAD) pada daerah tersebut karena perusahaan akan membayar pajak yang lebih tinggi. oleh karena itu selayaknya upah para pekerja juga akan meningkat. Karena hal tersebut, Produk Domestik Regional Bruto (PDRB) menjadi salah satu bahan pertimbangan dalam penetapan upah minimum di suatu daerah. Berikut adalah daftar UMK 5 (lima) kota/kabupaten yang berada di wilayah Barlingmascakeb tahun 2016-2019. 
Tabel 1

Upah Minimum Kabupaten/Kota di Provinsi Jawa Tengah (rupiah)

\begin{tabular}{|c|c|c|c|c|}
\hline \multirow[b]{2}{*}{ Kabupaten } & \multicolumn{4}{|c|}{ Upah Minimum Kabupaten/Kota } \\
\hline & 2016 & 2017 & 2018 & 2019 \\
\hline Banjarnegara & 1.265.000,- & 1.370.000,- & 1.490.000,- & $1.610 .00 C$ \\
\hline Kebumen & 1.324.600,- & 1.433.900,- & 1.560.000,- & $1.686 .00 C$ \\
\hline Banyumas & 1.350.000,- & 1.461.400,- & 1.589.000,- & $1.750 .00 C$ \\
\hline Purbalingga & 1.377.500,- & 1.522.500,- & 1.655.200,- & $1.788 .50 C$ \\
\hline Cilacap & 1.608.000,- & 1.693.689,- & 1.841.209;- & $1.989 .05 \varepsilon$ \\
\hline
\end{tabular}

Sumber:Disnakertrans Provinsi Jateng, 2020.

Dari tabel di atas dapat disimpulkan bahwa semenjak tahun 2016-2019 untuk wilayah Barlingmascakeb yang terdiri dari Kabupaten Banjarnegara, Kabupaten Purbalingga, Kabupaten Banyumas, Kabupaten Cilacap dan Kabupaten Kebumen. Kabupaten Banjarnegara menjadi kabupaten/kota yang memiliki Upah Minimum Kabupaten/Kota (UMK) terendah di daerah Barlingmascakeb

Terdapat banyak penelitian yang telah dilakukan, dimana penelitian tersebut menggunakan faktor-faktor yang mempengaruhi keputusan penetapan nilai upah minimum. Seperti penelitian yang dilakukan oleh Eka Nursakinah (2017), yang menunjukkan bahwa variabel Kebutuhan Hidup Layak (KHL) memiliki pengaruh positif dan signifikan terhadap penetapan upah minimum, artinya KHL atau kebutuhan hidup masyarakat dari waktu ke waktu selalu mengalami kenaikkan, untuk itu pemerintah/dewan pengupahan berupaya meningkatkan upah minimum agar masyarakat dapat mememnuhi kebutuhan hidup sehariharinya. Hasil penelitian lainnya yang dilakukan oleh Armidi (2018) menyatakan bahwa Indeks Harga Konsumen (IHK) berpengaruh positif dan signifikan terhadap penetapan upah minimum, artinya bahwa tinggi rendahnya IHK memiliki pengaruh terhadap Upah Minimum Provinsi Jambi sedangkan hasil penelitian berbeda dilakukan oleh Eka Nursakinah (2017) memperlihatkan hasil bahwa Indeks Harga Konsumen (IHK) tidak berpengaruh terhadap penetapan upah minimum. Hal tersebut dikarenakkan apabila IHK terjadi fluktuasi, upah minimum di Jabodetabek tetap mengalami kenaikkan.

Adapula penelitian lainnya yang dilakukan oleh Ilham Kristanto (2013) menunjukkan bahwa variabel Produk Domestik Regional Bruto (PDRB) berpengaruh secara signifikan dan positif terhadap penetapan upah minimum artinya dengan kenaikkan PDRB yang juga pertumbuhan ekonomi yang meningkat, maka akan meningkatkan pendapatan per kapita. Sehingga kenaikkan upah minimum Kabupaten Jember akan terus berlanjut. Hasil berbeda 
ditunjukkan oleh Nurtiyas (2016) yang menyatakan bahwa PDRB tidak berpengaruh terhadap penetapan nilai upah minimum provinsi. Hal tersebut dikarenakan penelitiannya dilakukan dengan jangka waktu yang pendek, yaitu lima tahun.

Berdasarkan uraian di atas, peneliti tertarik untuk melakukan penelitian dengan judul "Analisis Faktor-Faktor Yang Mempengaruhi Keputusan Penetapan Upah Minimum Kabupaten/Kota Di Wilayah Barlingmascakeb".

\section{Perumusan Masalah}

$\begin{array}{cll}\text { Besar } & \text { kecilnya suatu } & \text { Upah } \\ \text { Minimum } & \text { Kabupaten/Kota } & \text { dapat }\end{array}$
dipengaruhi oleh beberapa faktor, seperti : Kebutuhan Hidup Layak (KHL), Indeks Harga Konsumen (IHK), dan Produk Domestik Regional Bruto (PDRB). Oleh karena itu, dalam penelitian ini dirumuskan permasalahan sebagai berikut:

1. Apakah Kebutuhan Hidup Layak (KHL) berpengaruh terhadap keputusan penetapan Upah Minimum Kabupaten/Kota (UMK) di Wilayah Barlingmascakeb?

2. Apakah Indeks Harga Konsumen (IHK) berpengaruh terhadap keputusan penetapan Upah Minimum Kabupaten/Kota (UMK) di Wilayah Barlingmascakeb?

3. Apakah Produk Domestik Regional Bruto (PDRB) berpengaruh terhadap keputusan penetapan Upah Minimum Kabupaten/Kota (UMK) di Wilayah Barlingmascakeb?

4. Apakah Kebutuhan Hidup Layak (KHL), Indeks Harga Konsumen (IHK) dan Produk Domestik Regional Bruto (PDRB) berpengaruh terhadap Keputusan Penetapan Upah Minimum Kabupaten/Kota (UMK) di Wilayah Barlingmascakeb?

\section{Tujuan Penelitian}

Berdasarkan rumusan masalah yang telah dikemukakan di atas, adapun tujuan yang ingin dicapai dari penelitian ini, antara lain :

1. Untuk mengetahui pengaruh Kebutuhan Hidup Layak (KHL) terhadap keputusan penetapan Upah Minimum Kabupaten/Kota (UMK) di Wilayah Barlingmascakeb.

2. Untuk mengetahui pengaruh Indeks Harga Konsumen (IHK) terhadap keputusan penetapan Upah Minimum Kabupaten/Kota (UMK) di Wilayah Barlingmascakeb. 
3. Untuk mengetahui pengaruh Produk Domestik Regional Bruto (PDRB) terhadap keputusan penetapan Upah Minimum Kabupaten/Kota (UMK) di Wilayah Barlingmascakeb.

4. Untuk mengetahui pengaruh Kebutuhan Hidup Layak (KHL), Indeks Harga Konsumen (IHK) dan Produk Domestik Regional Bruto (PDRB) terhadap Keputusan Penetapan Upah Minimum Kabupaten/Kota (UMK) di Wilayah Barlingmascakeb.

\section{METODE PENELITIAN}

\section{Lokasi Penelitian}

Penelitian ini dilakukan di Badan Pusat Statistik (BPS) Kabupaten Banjarnegara. Alamat Jl. Selamanik No.33, Kutabanjarnegara, Kec. Banjarnegara, Banjarnegara, Jawa Tengah 53415. Data yang digunakan yaitu data KHL, IHK dan PDRB dari tahun 20102016 untuk wilayah Barlingmascakeb (Kabupaten Banjarnegara, Kabupaten Purbalingga, Kabupaten Banyumas, Kabupaten Cilacap, dan Kabupaten Kebumen). Data diambil dari www.bps.go.id

\section{Jenis Penelitian}

Penelitian ini menggunakan data kuantitatif

\section{Variabel Penelitian}

a Variabel bebas (independent variable: Kebutuhan Hidup Layak $\left(\mathrm{X}_{1}\right)$, Indeks Harga Konsumen $\left(\mathrm{X}_{2}\right)$ dan Produk Domestik Regional Bruto $\left(\mathrm{X}_{3}\right)$

b Variabel terikat (dependent variable): Upah Minimum Kabupaten/Kota (Y)

\section{Definisi Konsep dan Operasional Variabel}

a. UMK

Definisi konsep : upah minimum adalah upah bulanan yang dibayarkan kepada pekerja oleh pemberi pekerja yang bertujuan untuk memenuhi Kebutuhan hidup tenaga kerja dan mencegah terjadinya eksploitasi tenaga kerja.

b. KHL

Definisi konsep : KHL adalah kebutuhan hidup sehari-hari masyarakat yang dijadikan dasar dalam penetapan upah minimum

c. IHK

Definisi konsep : Upah minimum ditetapkan dengan mempertimbangkan harga kebutuhan pokok yang tercemin dalam IHK.

d. PDRB 
Definisi konsep : PDRB digunakan untuk mengukur produktivitas tenaga kerja, apabila terjadi kenaikan maka upah minimum selayaknya ditingkatkan

\section{Populasi, Sampel dan Teknik Sampel}

a. Populasi penelitian

Populasi dalam penelitian ini adalah wilayah Barlingmascakeb, yang terdiri dari Kabupaten Banjarnegara, Kabupaten Purbalingga, Kabupaten Banyumas, Kabupaten Cilacap, dan Kabupaten Kebumen dengan metode pengamatan mulai dari tahun 2010 hingga 2016.

b. Sampel Penelitian

Sampel yang digunakan dalam penelitian ini adalah wilayah Barlingmascakeb, yang terdiri dari Kabupaten Banjarnegara, Kabupaten Purbalingga, Kabupaten Banyumas, Kabupaten Cilacap, dan Kabupaten Kebumen.

\section{c. Teknik Sampel}

Teknik pengambilan sampel yang digunakan dalam penelitian ini yaitu menggunakan metode sampel jenuh

\section{Teknik Analisis Data}

Adapun teknik analisis data yang digunakan dalam penelitian ini adalah :

Uji asumsi klasik (uji normalitas, uji heterokedastisitas, uji multikolonieritas dan uji autokorelasi), uji regresi linier berganda dan uji hipotesis (uji t, uji F dan uji koefisien determinasi).

\section{HASIL DAN PEMBAHASAN}

\section{Hasil Uji Asumsi Klasik}

a. Uji Normalitas

Tabel 2

Uji Kolmogorov-Smirnov

\begin{tabular}{lrr} 
& \multicolumn{2}{c}{ Standardized Residual } \\
\hline Normal Parameters ${ }^{\mathrm{a}, \mathrm{b}}$ & $\mathrm{N}$ & 35 \\
\cline { 2 - 3 } & Mean &, 0000000 \\
\hline Most Extreme Differences & Std. Deviation &, 93933644 \\
\cline { 2 - 3 } & Absolute &, 080 \\
\cline { 2 - 3 } & Positive &, 074 \\
\hline Test Statistic & Negative &,- 080 \\
\hline Asymp. Sig. (2-tailed) & &, 080 \\
\hline
\end{tabular}

Sumber : Data sekunder yang diolah, 2020

Berdasarkan tabel di atas menunjukkan bahwa (Asymp. Sig.2tailed) sebesar 0,200 yang berarti nilai signifikansi $>0,05$ sehingga nilai residual berdistribusi secara normal.

b. Uji heterokedastisitas

Tabel 3

Hasil Uji Heterokedastisitas

\begin{tabular}{|c|c|c|c|c|c|}
\hline \multirow[b]{2}{*}{ Model } & \multicolumn{2}{|c|}{$\begin{array}{l}\text { Unstandardized } \\
\text { Coefficients }\end{array}$} & \multirow{2}{*}{$\begin{array}{c}\text { Standardize } \\
d \\
\text { Coefficients } \\
\text { Beta } \\
\end{array}$} & \multirow[b]{2}{*}{$\mathrm{T}$} & \multirow[b]{2}{*}{ Sig. } \\
\hline & B & Std. Error & & & \\
\hline $\begin{array}{l}1 \text { (Constan } \\
\text { t) }\end{array}$ & $\begin{array}{r}3950124,21 \\
8 \\
\end{array}$ & $\begin{array}{r}5412317,60 \\
8\end{array}$ & & ,730 & ,471 \\
\hline $\mathrm{KHL}$ &, 014 &, 042 & , 171 &, 343 &, 734 \\
\hline IHK & $-153,790$ & 320,553 &,- 087 &,- 480 &, 635 \\
\hline PDRB & $8,792 E-5$ &, 000 & ,138 & 688 & ,497 \\
\hline Tahun & $-381613,279$ & 411610,567 &,- 439 &,- 927 & ,361 \\
\hline
\end{tabular}

Dari tabel di atas masing-masing variabel memiliki nilai signifikan $>0,05$ jadi dapat disimpulkan bahwa tidak terjadi gejala heteroskedastisitas. 
c. Uji multikolonieritas

Tabel 4

Hasil Uji Multikolinieritas

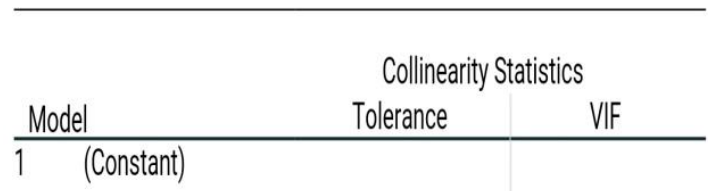

\begin{tabular}{lrl}
\hline KHL &, 119 & 8,396 \\
\hline HKK &, 904 & 1,106 \\
\hline PDRB &, 742 & 1,348 \\
\hline Tahun &, 133 & 7,515 \\
\hline
\end{tabular}

Sumber : Data sekunder yang diolah, 2020

Berdasarkan tabel di atas masingmasing variabel memiliki nilai tolerance > 0,100 dengan nilai VIF $<10$, maka dapat disimpulkan bahwa nilai tolerance dan VIF diatas tidak terjadi multikolinieritas.

d. Uji autokorelasi

Tabel 5

Uji Autokorelasi

\begin{tabular}{rl|r|r|r|r}
\hline Model & R & R Square & $\begin{array}{c}\text { Adjusted R } \\
\text { Square }\end{array}$ & $\begin{array}{c}\text { Std. Error of } \\
\text { the } \\
\text { Estimate }\end{array}$ & $\begin{array}{c}\text { Durbin- } \\
\text { Watson }\end{array}$ \\
\hline 1 &, $994^{\mathrm{a}}$ &, 987 & 985 & 2964458,26 & 2,728 \\
\hline
\end{tabular}

Sumber:Data sekunder yang diolah, 2020

Berdasarkan nilai hitung di atas, dapat dinyatakan bahwa penelitian ini bebas dari masalah autokorelasi.

\section{Hasil Uji Regresi Linier Berganda}

Tabel 6

Hasil Uji Regresi Linier Berganda

\begin{tabular}{|c|c|c|c|c|c|}
\hline \multirow[b]{2}{*}{ Model } & Unstandardizec & Coefficients & $\begin{array}{c}\text { Standardize } \\
d \\
\text { Coefficient } \\
s\end{array}$ & \multirow[b]{2}{*}{$\mathrm{T}$} & \multirow[b]{2}{*}{ Sig. } \\
\hline & B & Std. Error & Beta & & \\
\hline 1 (Constan & - & 9031302,42 & & 142 &, 888 \\
\hline t) & 1284577,065 & 0 & & & \\
\hline KHL &, 941 &, 070 & ,807 & 13,414 & ,000 \\
\hline IHK & $-501,078$ & 534,894 & -020 &,- 937 &, 356 \\
\hline PDRB &, 000 &, 000 & 018 &, 734 &, 469 \\
\hline Tahun & $\begin{array}{r}2284156,59 \\
4\end{array}$ & 686836,911 & , 189 & 3,326 & ,002 \\
\hline
\end{tabular}

Sumber : Data sekunder yang diolah, 2020

$\mathrm{Y}=-1.284 .577,065+0,941 *(\mathrm{KHL})-$

$501,078 *(\mathrm{IHK})+0,000 *(\mathrm{PDRB})+\mathrm{e}$

Berdasarkan persamaan diatas maka dapat kita interpretasikan beberapa hal antara lain sebagai berikut :

a. Persamaan regresi di atas dapat dijabarkan sebagai berikut :

Nilai konstanta sebesar -1.284.577,065 artinya UMK dengan mengesampingkan besarnya KHL, IHK dan PDRB adalah sebesar -1.284.577,065.

b. $Y=0,941 \mathrm{KHL}$

Artinya variabel KHL memiliki nilai koefisien regresi linier positif sebesar 0,941, artinya bahwa KHL terhadap peningkatan UMK berpengaruh positif. Hal ini menggambarkan apabila terjadi kenaikkan nilai KHL sebesar $1 \%$ maka akan menyebabkan kenaikkan nilai UMK sebesar 0,941 dengan asumsi variabel independen lainnya dianggap tetap. 
c. $\mathrm{Y}=-501,078 \mathrm{IHK}$

Artinya nilai koefisien regresi IHK negatif sebesar $-501,078$ menunjukkan bahwa IHK terhadap peningkatan UMK berpengaruh negatif. Hal ini menggambarkan apabila terjadi penurunan nilai IHK sebesar $1 \%$ maka akan menyebabkan penurunan UMK sebesar 501,078 dengan asumsi variabel inedependen lainnya dianggap konstan.

d. $Y=0,000$ PDRB

Artinya tidak ada perubahan dari variabel PDRB terhadap UMK. Nilai koefisien tersebut menunjukkan bahwa tidak adanya kenaikkan maupun penurunan (stagnan) terhadap nilai UMK.

\section{Hasil Uji Hipotesis}

a. Uji t

Tabel 7

Hasil Uji t

\begin{tabular}{|c|c|c|c|c|c|}
\hline \multirow[b]{2}{*}{ Model } & \multicolumn{2}{|c|}{$\begin{array}{l}\text { Unstandardized } \\
\text { Coefficients }\end{array}$} & \multirow{2}{*}{$\begin{array}{l}\text { Standardize } \\
d \\
\text { Coefficients } \\
\text { Beta }\end{array}$} & \multirow[b]{2}{*}{$\mathrm{T}$} & \multirow[b]{2}{*}{ Sig. } \\
\hline & B & Std. Error & & & \\
\hline 1 (Constan & - & 9031302,42 & & -142 & ,888 \\
\hline t) & 1284577,065 & 0 & & & \\
\hline KHL &, 941 &, 070 &, 807 & 13,414 &, 000 \\
\hline IHK & $-501,078$ & 534,894 &,- 020 &,- 937 &, 356 \\
\hline PDRB &, 000 &, 000 &, 018 &, 734 &, 469 \\
\hline Tahun & $\begin{array}{r}2284156,59 \\
4\end{array}$ & 686836,911 & ,189 & 3,326 &, 002 \\
\hline
\end{tabular}

1. Kebutuhan Hidup Layak (KHL) berpengaruh positif dan signifikan terhadap Keputusan Penetapan
Upah Minimum Kabupaten/Kota di Wilayah Barlingmascakeb.

Variabel KHL memiliki nilai $t_{\text {hitung }}>t_{\text {tabel }}$ dan nilai signifikansi $<0,05$. Dengan demikian dapat disimpulkan bahwa Ha diterima dan Ho ditolak. Sehingga, hipotesis yang berbunyi Kebutuhan Hidup Layak (KHL) berpengaruh positif dan signifikan terhadap Keputusan Penetapan Upah Minimum Kabupaten/Kota di Wilayah Barlingmascakeb diterima.

$\mathrm{H}_{1}$ : Kebutuhan Hidup Layak (KHL) berpengaruh positif dan signifikan terhadap Keputusan Penetapan Upah Minimum Kabupaten/Kota di Wilayah Barlingmascakeb.

\section{Indeks Harga Konsumen (IHK)} berpengaruh positif dan signifikan terhadap Keputusan Penetapan Upah Minimum Kabupaten/Kota di Wilayah Barlingmascakeb.

Variabel IHK memiliki nilai $\mathrm{t}_{\text {hitung }}<\mathrm{t}_{\text {tabel }}$ dan nilai signifikansi $>0,05$. Dengan demikian dapat disimpulkan bahwa Ha ditolak dan Ho diterima. Sehingga, hipotesis yang berbunyi Indeks Harga Konsumen (IHK) berpengaruh positif dan signifikan terhadap Keputusan Penetapan Upah Minimum Kabupaten/Kota di Wilayah Barlingmascakeb ditolak. 
$\mathrm{H}_{2}$ : Indeks Harga Konsumen (IHK) tidak berpengaruh negatif dan tidak signifikan terhadap Keputusan Penetapan Upah Minimum Kabupaten/Kota di Wilayah Barlingmascakeb.

\section{Produk Domestik Regional Bruto} (PDRB) berpengaruh positif dan signifikan terhadap Keputusan Penetapan Upah Minimum Kabupaten/Kota di Wilayah Barlingmascakeb

Variabel PDRB memiliki nilai $\mathrm{t}_{\text {hitung }}<\mathrm{t}_{\text {tabel }}$ dan nilai signifikansi $>0,05$. Dengan demikian dapat disimpulkan bahwa Ha diterima dan Ho ditolak. Sehingga, hipotesis yang berbunyi Produk Domestik Regional Bruto (PDRB) berpengaruh positif dan signifikan terhadap Keputusan Penetapan Upah Minimum Kabupaten/Kota di Wilayah Barlingmascakeb diterima.

$\mathrm{H}_{3}$ : Produk Domestik Regional Bruto (PDRB) tidak berpengaruh positif dan tidak signifikan terhadap Keputusan Penetapan Upah Minimum Kabupaten/Kota di Wilayah Barlingmascakeb.

b. Uji F

Tabel 8 Hasil Uji F

\begin{tabular}{|c|c|c|c|c|c|}
\hline Model & $\begin{array}{l}\text { Sum of } \\
\text { Squares }\end{array}$ & df & Mean Square & $\mathrm{F}$ & Sig. \\
\hline 1 Regression & $\begin{array}{r}20100904430 \\
000000,000\end{array}$ & 4 & $\begin{array}{r}502522610700 \\
0000,000\end{array}$ & 571,827 &, $000^{\circ}$ \\
\hline Residual & $\begin{array}{r}26364038360 \\
0000,000 \\
\end{array}$ & 30 & $\begin{array}{r}878801278800 \\
0,000\end{array}$ & & \\
\hline Total & $\begin{array}{r}20364544810 \\
000000,000\end{array}$ & 34 & & & \\
\hline
\end{tabular}

Sumber : Data sekunder yang diolah, 2020

H4 : Kebutuhan Hidup Layak (KHL), Indeks Harga Konsumen (IHK) dan Produk Domestik Regional Bruto (PDRB) berpengaruh secara simultan dan signifikan terhadap Keputusan Penetapan Upah Minimum Kabupaten/Kota di Wilayah Barlingmascakeb.

Berdasarkan Tabel hasil Uji F diatas menunjukkan bahwa $F_{\text {hitung }}>F_{\text {tabel }}$ dan tingkat signifikan $<0,05$ maka dapat dikatakan Kebutuhan Hidup Layak (KHL), Indeks Harga Konsumen (IHK) dan Produk Domestik Regional Bruto (PDRB) secara bersama-sama (simultan) mempengaruhi Keputusan Penetapan Upah Minimum Kabupaten/Kota di Wilayah Barlingmascakeb.

c. Uji koefisien determinasi

Tabel 9

Hasil Uji Koefisien Determinasi $\left(\mathrm{R}^{2}\right)$

\begin{tabular}{ll|l|r|r|r} 
Model & $R$ & R Square & $\begin{array}{c}\text { Adjusted R } \\
\text { Square }\end{array}$ & $\begin{array}{r}\text { Std. Error of } \\
\text { the Estimate }\end{array}$ & $\begin{array}{r}\text { Durbin- } \\
\text { Watson }\end{array}$ \\
\hline 1 & $994^{\mathrm{a}}$ &, 987 &, 985 & 2964458,262 & 2,728
\end{tabular}

Sumber : Data sekunder yang diolah, 2020

Berdasarkan tabel di atas, diperoleh nilai R Square sebesar 0,987 (98,7\%). Hal 
tersebut menunjukkan bahwa kemampuan variabel Independen (KHL, IHK dan PDRB) dalam menjelaskan besarnya pengaruh terhadap variabel dependen UMK selama 7 tahun (2010-2016) adalah sebesar (98,7\%), sedangkan sisanya sebesar $1,3 \%$ dipengaruhi oleh variabel lain yang tidak termasuk dalam penelitian ini.

\section{PEMBAHASAN}

\section{Pengaruh KHL terhadap Keputusan Penetapan UMK di Wilayah Barlingmascakeb}

KHL berpengaruh positif dan signifikan terhadap keputusan penetapan UMK di wilayah Barlingmascakeb. Hal tersebut karena berdasarkan UU Ketenagakerjaan No 13 Tahun 2003 dan PP tentang Pengupahan No 78 Tahun 2015. Pemerintah menetapkan standar Kebutuhan Hidup Layak (KHL) sebagai dasar pertimbangan dalam penetapan upah minimum. Sehingga apabila terjadi peningkatan nilai Kebutuhan Hidup Layak (KHL) masyarakat maka akan diikuti dengan peningkatan upah minimum untuk memenuhi kebutuhan hidup masyarakat tersebut.

Hasil ini konsisten dan sejalan dengan penelitian dari ilham Kristanto (2013) yang berjudul “Analisis Penetapan
Upah Minimum Kabupaten di Jember" bahwa KHL berpengaruh secara signifikan dan memiliki koefisien positif terhadap upah minimum Kabupaten Jember periode 1990 - 2011.

Dengan adanya penelitian ini membuktikan bahwa semakin meningkatnya nilai/taraf kebutuhan hidup layak yang terjadi di kalangan/pekerja, maka akan diikuti kenaikkan nilai upah minimum kabupaten/kota di wilayah Barlingmascakeb pada tahun berikutnya.

Variabel KHL berpengaruh positif dan signifikan dikarenakan variabel KHL merupakan variabel utama atau sebagai dasar pertimbangan dalam menetapkan nilai upah minimum kabupaten/kota di wilayah Barlingmascakeb.

\section{Pengaruh IHK terhadap \\ Keputusan Penetapan UMK di Wilayah Barlingmascakeb \\ IHK tidak berpengaruh dan tidak} signifikan terhadap keputusan penetapan UMK di wilayah Barlingmascakeb.

Hasil ini sama seperti penelitian dari Eka Nursakinah (2017) yang berjudul "Analisis factor-faktor yang mempengaruhi penetapan upah minimum di Jabodetabek tahun 2007-2016" bahwa IHK tidak berpengaruh terhadap penetapan upah minimum di Jabodetabek. 
Dengan adanya penelitian ini membuktikan bahwa Indeks Harga Konsumen atau disingkat IHK yang mana menjadi tolak ukur inflasi tidak berpengaruh negatif terhadap keputusan penetapan UMK di wilayah Barlingmascakeb. Hal tersebut dibuktikan apabila terjadi fluktuasi harga barang, upah minimum kabupaten/kota di wilayah Barlingmascakeb tetap meningkat.

\section{Pengaruh PDRB terhadap Keputusan Penetapan UMK di Wilayah Barlingmascakeb}

PDRB tidak berpengaruh dan tidak signifikan terhadap keputusan penetapan UMK di wilayah Barlingmascakeb. Selanjutnya penelitian ini juga membuktikan bahwa apabila PDRB mengalami kenaikkan maupun penurunan tidak berpengaruh terhadap keputusan penetapan UMK di wilayah Barlingmascakeb.

Hasil ini sama seperti penelitian dari Eka Nursakinah (2017) yang berjudul "Analisis factor-faktor yang mempengaruhi penetapan upah minimum di Jabodetabek tahun 2007-2016" bahwa PDRB berpengaruh positif terhadap penetapan upah minimum di Jabodetabek.

Hasil penelitian ini sesuai dengan teori yang dinyatakan oleh Gaol dalam Kristanto (2013) yang menyatakan bahwa apabila terjadi peningkatan produktivitas tenaga kerja yang dapat dilihat dari output PDRB maka upah minimum selayaknya ditingkatkan. Ketika PDRB mengalami kenaikkan, maka akan diikuti juga kenaikkan nilai UMK di wilayah Barlingmascakeb. Tetapi saat PDRB mengalami penurunan, nilai UMK tidak mengalami penurunan.

4. Kebutuhan Hidup Layak (KHL), Indeks Harga Konsumen (IHK) dan Produk Domestik Regional Bruto (PDRB) berpengaruh simultan dan signifikan terhadap Keputusan Penetapan Upah Minimum Kabupaten/Kota di wilayah Barlingmascakeb.

Kebutuhan Hidup Layak (KHL), Indeks Harga Konsumen (IHK) dan Produk Domestik Regional Bruto (PDRB) berpengaruh secara bersama-sama (simultan) dan signifikan terhadap Keputusan Penetapan Upah Minimum Kabupaten/Kota di Banjarnegara.

\section{KESIMPULAN DAN SARAN}

\section{Kesimpulan}

Berdasarkan hasil penelitian dan pembahasan dalam bab sebelumnya, dapat disimpulkan bahwa :

a. Kebutuhan Hidup Layak (KHL) berpengaruh positif dan signifikan 
terhadap keputusan penetapan UMK di wilayah Barlingmascakeb. Hal tersebut karena berdasarkan UU Ketenagakerjaan No 13 Tahun 2003 dan PP tentang Pengupahan No 78 Tahun 2015. Pemerintah menetapkan standar Kebutuhan Hidup Layak (KHL) sebagai dasar pertimbangan dalam penetapan upah minimum. Sehingga apabila terjadi peningkatan nilai Kebutuhan Hidup Layak (KHL) masyarakat maka akan diikuti dengan peningkatan upah minimum untuk memenuhi kebutuhan hidup masyarakat tersebut.

b. IHK tidak berpengaruh dan tidak signifikan terhadap keputusan penetapan UMK di wilayah Barlingmascakeb. Hal tersebut dikarenakan ketika Indeks Harga Konsumen (IHK) yang menjadi tolak ukur inflasi mengalami fluktuasi (kenaikkan/penurunan harga barang dan jasa), upah minimum kabupaten/kota di wilayah Barlingmascakeb tetap meningkat.

c. PDRB tidak berpengaruh tidak signifikan terhadap keputusan penetapan UMK di wilayah Barlingmascakeb. Artinya ketika PDRB mengalami kenaikkan, maka akan diikuti juga kenaikkan nilai
UMK di wilayah Barlingmascakeb. Tetapi saat PDRB mengalami penurunan, nilai UMK tidak mengalami penurunan. Hal tersebut menunjukkan produktivitas tenaga kerja/buruh di wilayah Barlingmascakeb mengalami peningkatan di setiap tahunnya.

\section{Saran}

Berdasarkan hasil analisis pembahasan dan kesimpulan pada penelitian ini, adapun saran - saran yang dapat diberikan melalui hasil penelitian ini agar mendapatkan hasil yang lebih baik yaitu :

1. Pemerintah diharapkan memperhatikan nilai Kebutuhan Hidup Layak (KHL) di setiap kabupaten/kota untuk meningkatkan UMK di daerah tersebut.

2. Penelitian ini menggunakan teknik analisis data dengan bantuan SPSS, diharapkan pada penelitian selanjutnya menggunakan bantuan program Eviews 8 agar mendapatkan hasil yang maksimal.

3. Bagi penelitian selanjutnya, diharapkan melakukan penelitian dengan menambahkan periode jangka waktu penelitiannya. Dan diharapkan pula untuk menambahkan variabel 
lain seperti tingkat partisipasi angkatan kerja, inflasi dan Pendapatan per Kapita.

\section{Daftar Pustaka}

Armidi, (2018). Pengaruh Tingkat Partisipasi Angkatan Kerja dan Indeks Harga Konsumen terhadap Upah Minimum Provinsi Jambi. Jurnal: Fakultas Ekonomi dan Bisnis, Universitas Jambi.

Bersales, Lisa Grace. (2014).Determinant of Regional Minimum Wage in the Philippines, Statistics Journal: Philippines. School of Statistic, University of the Philippines Diliman.

Eka Nursakinah, (2017). Analisis FaktorFaktor Yang Mempengaruhi Penetapan Upah Minimum Di Jabodetabek Tahun 2007 - 2016. Skripsi: Fakultas Ekonomi dan Bisnis Islam, UIN Sunan Kalijaga Yogyakarta.

Febrika Nurtiyas, (2016). Analisis Faktor - Faktor Yang Mempengaruhi Upah Minimum Provinsi Di Pulau Jawa Tahun 2010 - 2014. Skripsi: Fakultas Ekonomi, Univeritas Negeri Yogyakarta.

Gaol S. Lumban, 2009. Aplikasi Faktor Pertimbangan Dalam Penetapan Upah Minimum. Makalah dalam Forum Konsultasi dan Komunikasi Dewan Pengupahan, Wisma Karya Jasa, Bogor.

Gujarati, Damodar N, Dawn C. Porter. 2013.

Dasar-Dasar
Ekonometrika, Jakarta : Salemba Empat.

https://www.hukumonline.com/klinik/det ail/ulasan/lt4c85f88b626af/langk ah-hukum-jika-upah-di-bawahstandar-minimum/ di akses pada tanggal 28 Desember 2019

https://www.hestanto.web.id/ketenagaker jaan/ di akses pada 12 Januari 2020

Ilham Kistanto. (2013). Analisis Penetapan Upah Minimum Kabupaten Jember, Skripsi: Jember, Fakultas Ekonomi, Universitas Jember.

Keputusan Menteri Tenaga Kerja No. 17 tahun 2005.

Keputusan Menteri Tenaga Kerja No. 13 tahun 2012.

Mankiw, N. Gregory. (2013). Macroeconomics. Cetakan 8, New York: Worth Publishers.

Mankiw, N. Gregory, Quah, Euston dan Wilson, Peter. (2012). Pengantar Ekonomi Makro. Edisi Asia, Jakarta: Salemba Empat.

Merdekawaty Rahmah, dkk, (2016). Analisis Faktor-Faktor Yang Mempengaruhi Upah Minimum Kabupaten/Kota Di Provinsi Jawa Tengah Menggunakan Model Spatial Autoregressive (SAR). Jurnal: GAUSSIAN, Volume 5, Nomor 3, Tahun 2016, Halaman 525-534. Universitas Diponegoro, Semarang.

Maya Panorama dan Lemiyana (2014). Pengaruh Upah Minimum Kota (UMK) Terhadap Kesempatan Kerja Dan Pengangguran Di Kota Palembang tahun 2004- 
2014. Jurnal : I-Finanance Vol. 3. No. 2. Desember 2017

Pasal $\quad 88 \quad$ Undang - $\quad$ Undang Ketenagakerjaan No. 13 tahun 2003.

Peraturan Presiden No. 78 tahun 2015 tentang Pengupahan.

Peraturan Menteri Ketenagakerjaaan No. 21 tahun 2016.

Peraturan Menteri Tenaga Kerja dan Transmigrasi No. 7 tahun 2013 tentang Upah Minimum.

Rusli, Hardijan. (2011). Hukum Ketenagakerjaan, Jakarta: Ghalia Indonesia.
Sofyan Yamin, Lien A, Rachmach, Heri Kurniawan. 2010. Regresi dan Korelasi Aplikasi dengan Software SPSS, EVIEWS, MINITAB, dan STATGRAPHICS. Jakarta : Salemba Empat.

Sadono Sukirno.( 2013). Makro Ekonomi Teori Pengantar Edisi Ketiga. Jakarta: PT Raja Grafindo Persada.

Todaro. (2011). Pembangunan Ekonomi. Jakarta: Erlangga.

Sugiyono, (2011). Metode Penelitian Kuantitatif dan Kualitatif dan $R \& D$. Bandung: Alfabeta. 